\title{
JAK and STAT gene mutations and JAK-STAT pathway activation in lympho- and myeloproliferative neoplasms
}

\author{
Michał Łączak, Martyna Kuczyńska, Joanna Grygier, Dominika Andrzejewska, \\ Wiktoria Grochowska, Hanna Gulaczyk, Krzysztof Lewandowski®D \\ Department of Hematology and Bone Marrow Transplantation, Medical Faculty, \\ Poznan University of Medical Sciences, Poznan, Poland
}

\begin{abstract}
Lympho- and myeloproliferative neoplasms are a very heterogeneous group of haematological malignancies originating from a haematopoietic stem cell (HSC). In most of them, the neoplastic transformation is a result of the acquisition of molecular defects by HSC or progenitor cells, impairing their proliferation, differentiation and maturation. Herein, the role of the Janus kinase-signal transduction and transcription activation (JAK-STAT) signalling pathway in the normal and neoplastic lympho- and myelopoiesis is presented. Particular attention is paid to the molecular aberrations of the JAK and STAT genes and their impact on JAK and STAT signalling pathway function and the mutation-driven mechanism of the lymphoid and myeloid cells neoplastic transformation. In the Authors' opinion, its early identification allows to incorporate the molecularly targeted drugs, including JAK-STAT pathway signalling inhibitors, to the therapeutic algorithm used and to improve the treatment results of lymphoid-and myeloid neoplasms.
\end{abstract}

Key words: lympho- and myeloproliferative neoplasms, Janus tyrosine kinases, signal transducer and activator of transcription proteins, molecular aberrations, malignant transformation

Hematology in Clinical Practice 2021; 12, 3-4: 89-104

\section{Introduction}

Haematopoiesis is a multi-stage and hierarchical process in which all types of blood cells are formed from marrow multi-potential stem cells. Each blood cell is derived from a multi-potential hematopoetic stem cell (HSC) [1]. The process of haematopoiesis is initiated by the division of HSCs; as a result, one daughter cell undergoes further differentiation, while the other remains in the pool of stem cells, ensuring self-renewal of the HSC population. The process of self-renewal and differentiation of HSC into daughter cells requires a suitable bone marrow microenvironment, composed of adipocytes, endothelial cells, osteoblasts and fibroblasts. Also, cells resulting from haematopoiesis - osteoclasts and bone marrow macrophages [2-5], play an important role in this process. The capacity for self-renewal is the basic feature that distinguishes stem cells from their later developmental stages. The divisions of daughter cells lead to the formation of more and more mature forms, up to extremely differentiated forms without the ability to divide. Regardless of their ability for self-renewal, haematopoietic stem cells can differentiate in many ways. According to the current state of knowledge, the process of haematopoiesis takes place within 11 major cell lines (Figure 1). HSC differentiation is a multi-stage process. During the first stage, HSC is transformed

Address for correspondence: Krzysztof Lewandowski, Katedra i Klinika Hematologii i Transplantacji Szpiku,

Uniwersytet Medyczny im. Karola Marcinkowskiego w Poznaniu, ul. Szamarzewskiego 84, 60-569 Poznań, Poland, e-mail: krzysztof.lewandowski@skpp.edu.pl

This article is available in open access under Creative Common Attribution-Non-Commercial-No Derivatives 4.0 International (CC BY-NC-ND 4.0) license, allowing to download articles and share them with others as long as they credit the authors and the publisher, but without permission to change them in any way or use them commercially. 


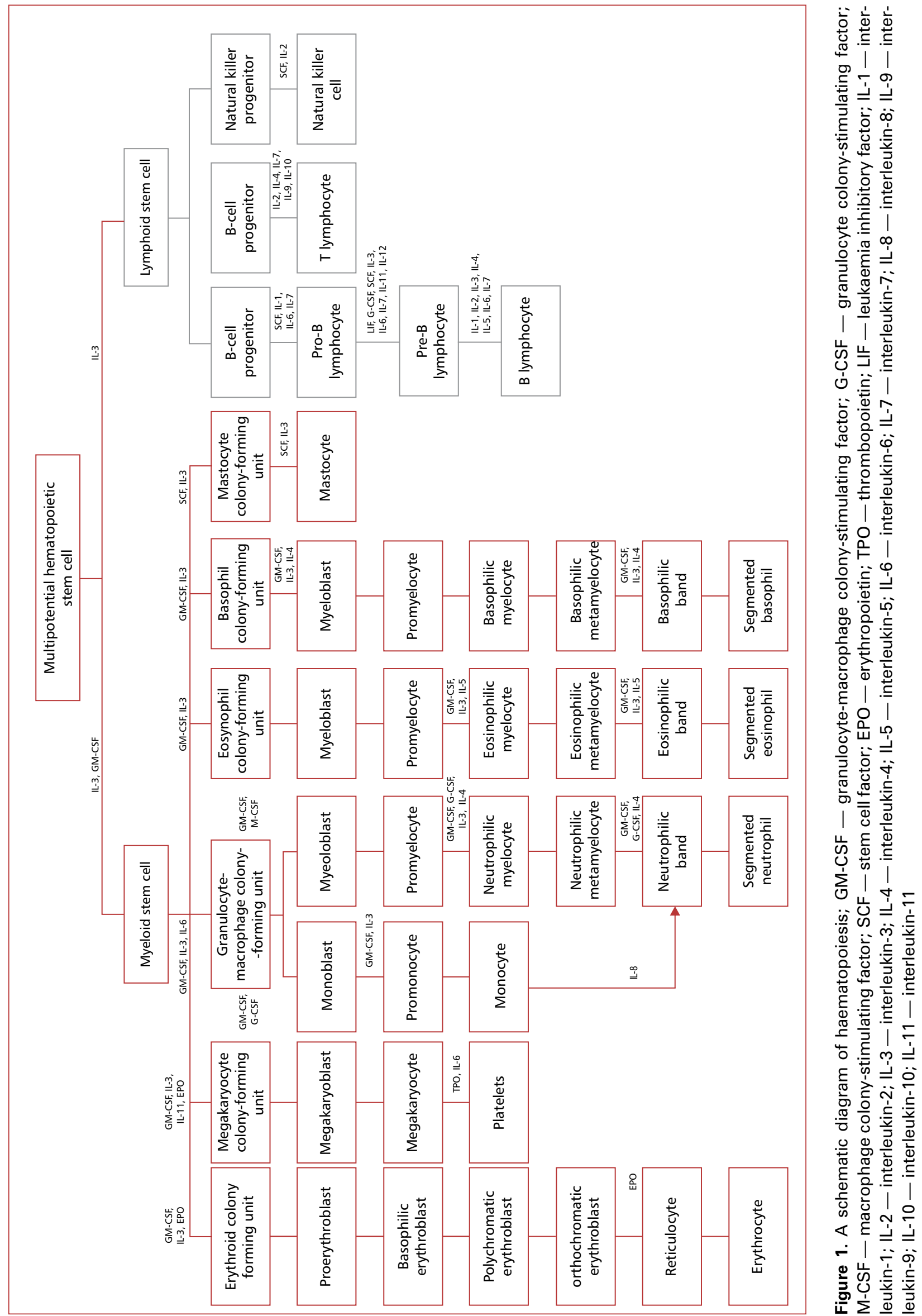




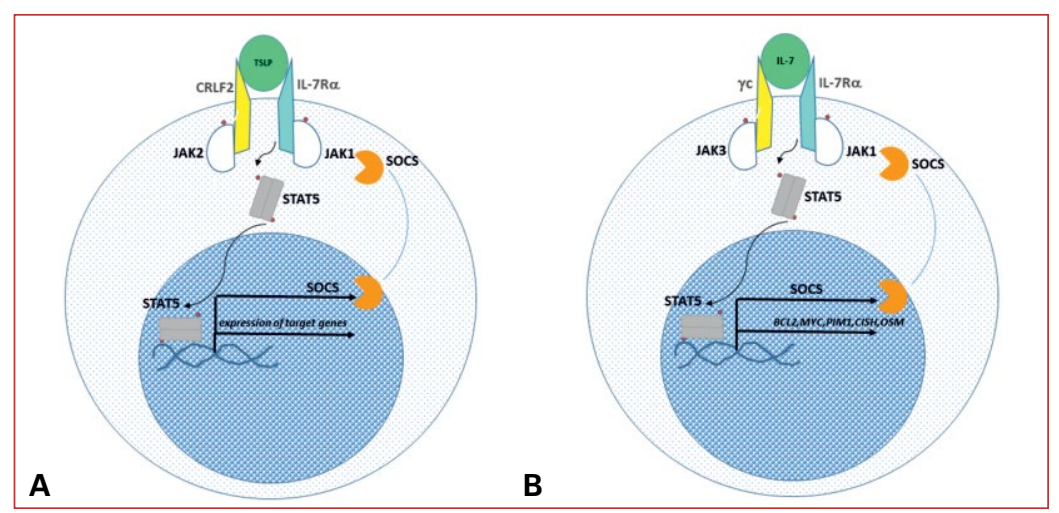

Figure 2. The mechanism of cell signaling induced by thymic stromal lymphopoietin (TSLP) (A) and interleukin-7 (IL-7) via the IL-7 receptor (B). Explanation of the abbreviations used; TSLP — thymic stromal lymphopoietin; IL-7R $\alpha$ — interleukin-7 receptor subunit alpha; CRLF2 - cytokine receptor-like factor 2; JAK — Janus tyrosine kinase; STAT5 - signalling and transcription protein; SOCS — the suppressor of cytokine signalling; BCL2 - B-cell lymphoma 2 protein; $M Y C$ - MYC proto-oncogene; PIM1 - PIM-1 proto-oncogene; CISH - cytokine-inducible SH2-containing protein; OSM - the oncostatin $M$ gene encoding the sequence of a pleiotropic cytokine from the interleukin- 6 family

into a multipotent progenitor (MPP), followed by the formation of common lymphoid progenitors (CLP) and common myeloid progenitors (CMP). The intensity of haematopoiesis within individual cell lines is controlled by the coordinated action of cytokines, transcription and epigenetic factors, and growth factors [6, 7]. A common precursor for all myelopoiesis is CFU-GEMM (colony-forming unit of granulocyte, erythrocyte, macrophage, megakaryocyte). Myelopoiesis stem cells gradually lose their ability to renew themselves, while retaining their multidirectional differentiation function. Under the influence of the cytokine game and the influence of the growth factors, CFU-GEMM transforms into targeted progenitor cells, and then the precursors of the erythropoietic line - units that form large, early erythroid colonies (BFU-E), erythroid colony-forming units (CFU-E), eosinophilopoietic line - units forming eosinophilic colonies (CFU-E), basophilopoietic line - basophilic colony forming units (CFU-Baso), mast cell line - mast cell colony-forming units (CFU-mast), monocytopoietic line - monocytic colony forming units (CFU-M), megakaryopoietic line - mast cell colony-forming units (CFU-mast) and neutrophilopoietic line granulocytic colony-forming units (CFU-G).

In the process of lymphopoiesis, the ability to differentiate precursor cells is fully preserved. The mechanism of proliferation and differentiation of B, T, and NK lymphocytes from lymphopoietic precursor cells (CLP) also depends on the number of environmental factors, including growth factors, cytokines, kinases (JAK, Kit-L), and surface molecules, such as Notch-1. Notch-1 which in cooperation with GATA-3 is involved in the process of $T$ lymphocytes differentiation via the receptor $\alpha \beta$, plays an extremely important role in this process. The receptor for interleukin-7 (IL-7) (CD127, IL-7R $\alpha)[8,9]$ plays a special role in the early stages of B- and T-lymphocyte proliferation and differentiation. Its activation by IL-7 leads to phosphorylation of JAK1 or JAK3 kinase, and the activation of JAK1-STAT5 or JAK3-STAT5 signal transduction pathway. It should be noted that activation of IL-7R simultaneously leads to the signal transduction along the PI3K-AKT and Ras-MAPK $[10,11]$ pathways. In the case of the IL-7 receptor, the JAK1 kinase is structurally and functionally related to the IL-7R subunit $\alpha$, and the JAK3 kinase to the $\gamma \mathrm{c}$ subunit of the receptor [12]. The mechanism of cell signalling induced by thymic stromal lymphopoietin (TSLP) and interleukin-7 (IL-7) via the IL-7 receptor is shown in Figure 2.

\section{Cytokines involved in the process of lympho- and myelopoiesis}

Cytokines and growth factors are glycoproteins that regulate the proliferation and differentiation of progenitor cells. They also control some functions of mature blood cells [13]. Cytokines are primarily survival factors and act as growth factors in higher concentrations. It should be kept in mind that survival is regulated by so-called "deadly cytokines" which include tumour necrosis factor-alpha (TNF alpha). The most important factors acting on haematopoietic stem cells include: Kit ligand (KL) - the Steel factor, FMS-like ty- 


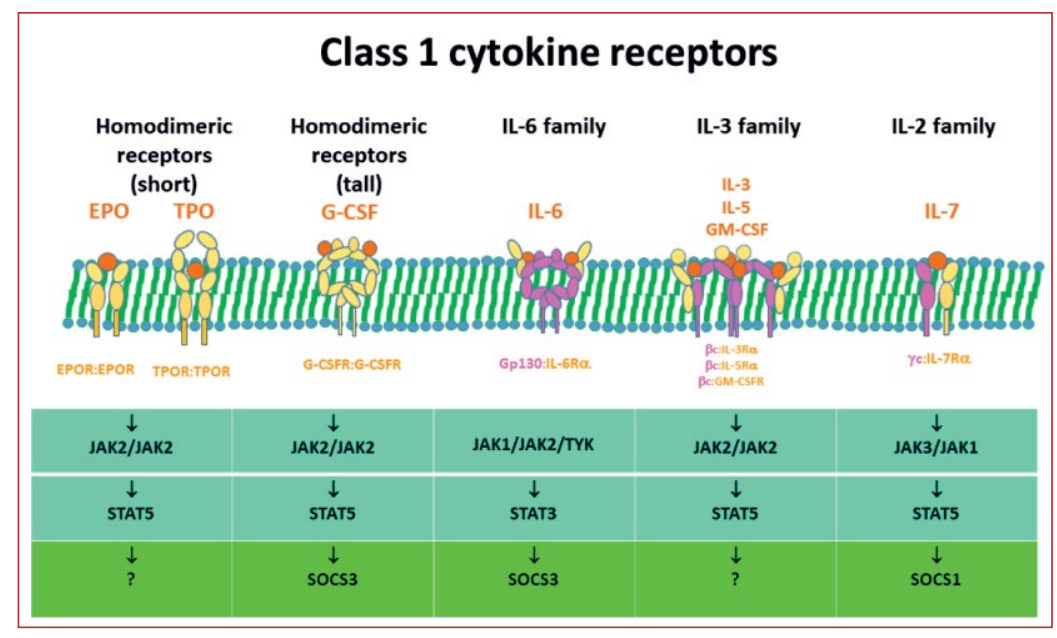

Figure 3. Cytokine-initiated cell signalling via the JAK-STAT pathway involved in haematopoiesis (acc. to [14]); IL — interleukin; IL-xR - the receptor for a specific $(x)$ type of interleukin; GM-CSF — granulocyte-macrophage colony-stimulating factor; GM-CSFR - granulocyte-macrophage colony-stimulating factor receptor; G-CSF — granulocyte colony-stimulating factor; G-CSFR - granulocyte colony-stimulating factor receptor; EPO - erythropoietin; EPOR - erythropoietin receptor; TPO — thrombopoietin; TPOR — thrombopoietin receptor; Gp130 - glycoprotein 130; $\beta \mathrm{c}$ - common beta chain; JAK - Janus tyrosine kinase; TYK - tyrosine-protein kinase TYK; STAT — signal transducer and activator of transcription protein; SOCS - suppressor of signal transduction by cytokines

rosine kinase 3 ligand (FLT-3 ligand), as well as factors affecting multi-potential progenitor cells: the granulocyte-macrophage colony-stimulating factor (GM-CSF) - the factor that stimulates the formation of granulocytes and macrophages; the granulocyte colony-stimulating factor (G-CSF), interleukin 3 (IL-3) and interleukin 6 (IL-6). The factors involved in the maturation and differentiation of targeted precursor cells include granulocytic growth factor (G-CSF), macrophage growth factor (M-CSF), interleukin 5 (IL-5), erythropoietin (EPO), and thrombopoietin (TPO) (Figure 3) [14].

The FLT3 receptor (fms-like tyrosine kinase 3 ) and the FLT3 ligand play a key role in the functioning of haematopoiesis. FLT3 plays an important role in initiating the expansion of early progenitor cells, and its proper function is essential not only for the maintenance of the HSC population but also for the growth of targeted common myeloid progenitor cells (CMP), granulocyte-monocyte progenitor (GMP) and macrophages and megakaryocyte-erythroid progenitor (MEP) cells [15-17].

\section{The role of the JAK-STAT signalling pathway in lympho- and myelopoiesis}

The course of both lympho- and myelopoiesis is dependent on the undisturbed interaction between cytokines and cytokine receptors on the surface of haematopoietic stem cells, as well as the Janus receptortyrosine kinase function, Janus tyrosine kinase-STAT protein interactions and STAT dimers/monomers binding the promoter sequences of target genes.

During the first stage, the binding of the cytokine/growth factor to the target receptor leads to its dimerization/oligomerization and the recruitment of JAK molecules. The JAK recruitment results in their phosphorylation by autophosphorylation and/or transphosphorylation mediated by another JAK molecule or another kinase from the tyrosine kinase family. An activated Janus kinase mediates phosphorylation of the target tyrosine molecule within the receptor. In this way, a docking site for the STAT molecules is created [18]. After the binding of the STAT molecule to the receptor, tyrosine phosphorylation occurs. The abovementioned process initiates the reorientation of STAT proteins and their homo- or heterodimerization. STAT dimerization is the result of an interaction between the SH2 domain on one STAT molecule and phosphorylated tyrosine on the other STAT molecule. After phosphorylation, STAT dimers translocate to the nucleus, bind to the target gene sequence via the DNA-binding domain, and initiate the process of transcription of target genes. The activity of STAT (except for STAT2) is controlled by serine-threonine kinases (e.g. ERK, p38, mTOR). The regulation of STAT activity is possible by serine phosphorylation in the transactivation domain (within the conserved PSMP motif) [19-21]. The conceptual structure of STAT3 and STAT5B molecules is shown in Figure 3 [14]. 


\section{Proteins involved in the signal transduction along the JAK-STAT pathway}

Janus tyrosine kinases

Cell signal transmission within the cell is complex and involves basic life functions, including cell cycle coordination. These processes involve protein kinases involved in the phosphorylation of several amino acids, including serine, threonine, histidine and tyrosine. So far, there have been distinguished two types of protein kinases serine-threonine kinases and tyrosine kinases. The network of protein kinases is formed by mitogen-activated protein kinases (MAPK), extracellular signal-regulated kinases (ERK), epidermal growth factor receptor (EGFR), Src kinase proto-oncogene (src), Abelson tyrosine-protein kinase (ABL), focal adhesion kinase (FAK) and Janus family kinase [22]. The JAK family consists of the JAK1, JAK2, JAK3 and TYK2 kinases. The NH2 portion of the JAK kinases contains two essential motifs: the Src homology domain (SH2) and the FERM domain (Four-point-one, Ezrin, Radixin, Moesin). The first one consists of the $\mathrm{JH} 3$ region and the $\mathrm{JH} 4$ domain. The FERM domain is involved in the binding of the kinase to the receptor, as well as to other proteins. It is also involved in the regulation of the catalytic activity of JAK kinase [23]. A characteristic feature of the Janus family kinases is the presence of domains with a high degree of homology: JH1 and JH2 [24]. The functional domain is the JH1 domain containing the YY motif within the activation loop. The JH2 domain (kinase-like domain), structurally similar to functional kinases, has no measurable biological activity, possibly due to the loss of formations responsible for the catalytic activity of the kinase and its binding to nucleotides [25-27]. However, the JH2 domain has a regulatory function concerning JAK2 and JAK3 kinase activity [28-31]. The detailed mechanism of this interaction has been discovered thanks to the studies of the mutant form of JAK2 V617F kinase in patients with Philadelphia negative myeloproliferative neoplasms. It has been shown in them that the presence of the $V 617 F$ mutation abolishes the inhibitory effect of the JH2 domain on JH1, which results in the constant constitutive activity of JAK2 V617F kinase in neoplastic cells [32].

\section{STAT proteins}

STAT (signal transducer and activator of transcription) family proteins are intracellular transcription factors mediating several cellular processes, including proliferation, differentiation, and their programmed death (apoptosis). STAT proteins are one of the major cell signal transducers in response to the action of various types of agonists on cell receptors, including growth factors, cytokines, and other protein ligands [33].

Some of them, including STAT5, have been shown to play a key role in cytokine-induced proliferation, self-renewal and survival of HSC [34, 35]. The normal function of both JAK1 and JAK2 has also been shown to play a key role in maintaining HSC homeostasis. The in vivo experimental model showed that the deletion of Jak1 leads to changes in the self-renewal of $\mathrm{HSC}$ and disrupts the process of cell differentiation in both the lymphoid and myeloid lineage [36]. The knock-out of the Jak2 gene leads to even greater consequences. Its deletion leads not only to ineffective haematopoiesis but also to the death of the embryo [37, 38].

The STAT family includes seven proteins STAT1, STAT2, STAT3, STAT4, STAT5a, STAT5b, STAT6. Each protein contains an N-terminal region, a coiled-coil domain, DNA binding domain, linker region, Src homology 2 domain and C-terminal transactivation domain [39, 40]. All STAT proteins share a common, highly conserved $\mathrm{N}$-terminal region sequence. It consists of a hydrophobic core that participates in the attachment of STAT dimers to DNA [41]. The coiled-coil domain consists of approximately 180 amino acids making up the $4 \alpha$-helices. They form a hydrophobic surface that allows STAT proteins to interact with other proteins [42]. The $\mathrm{SH} 2$ domain is responsible for the process of combining the STAT protein with phosphotyrosine of the activated JAK tyrosine kinase [21]. The structure of the DNA binding domain allows STAT proteins to bind to specific DNA sequences and thus act as transcription factors. Each STAT protein participates in different cellular processes. And so, STAT1 is involved in the expression of genes that determine the viability and survival of cells, as well as in the response of cells to pathogens, including Candida sp. [43, 44]. STAT2 is involved in signalling through the IFN$-\alpha / \beta$ receptor. In response to the binding of the JAK tyrosine kinase with the interferon, there is formed STAT1-STAT2 heterodimer, to which the p48 [interferon regulatory factor 9 (IRF9)] also binds. The resulting complex called ISGF3 (interferon stimulated gene factor 3 ) functions as a transactivator because it cannot bind to the DNA structure itself $[45,46]$. It plays a key role in the processes of growth of cellular differentiation, apoptosis and cell migration, as well as in the process of DNA methylation and nuclear chromatin modification 
[47-49]. STAT4, STAT5A and STAT5B proteins play a slightly different role. STAT4 participates in the process of maturation and development of Th1 cells. It also plays an important role in the initiation of interferon-gamma synthesis, as well as the control of the expression of certain transcription factors $[50,51]$. A different role is played by the STAT5A and STAT5B proteins, which show $90 \%$ homology in terms of the amino acid sequence. They participate in the control of cell growth and division, their specialization, and, at the end of their life, in their apoptosis [52]. STAT6 mediates signalling with the participation of IL-4 and IL-13. It plays an important role in the process of the immune response of $T$ lymphocytes and the formation of type 2 (Th2) lymphocytes [53].

STAT proteins are activated by phosphorylation of a single tyrosine at 701 position by activated JAK kinase [54]. As a result of tyrosine phosphorylation, individual molecules of the STAT protein form dimers through the interaction between the $\mathrm{SH} 2$ domain and the C-terminal transactivation domain [55]. In the case of the STAT1, STAT3, STAT4, STAT5A and STAT5B proteins, these are homodimers. In some cases, however, the formation of heterodimers (e.g. STAT1 and STAT2 as well as STAT1 and STAT3) occurs [56].

Phosphorylated STAT1 homodimers or STAT1/STAT2 heterodimers are translocated to the nucleus with the participation of importin- $\alpha 5$. This phenomenon has not been confirmed in the case of STAT1 monomers. STAT1 dimers bind to two $5 \alpha$ importin molecules, due to the presence of lysine-rich fragments of nuclear localization signals (NLSs) in the DNA binding domain. The presence of leucine at position 407 in the DNA binding domain is crucial for STAT1 protein transport into the nucleus. Its role is confirmed by the lack of STAT1 binding to importin- $\alpha 5$ in the presence of the Leu407Ala STAT1 mutation $[57,58]$. The transport of STAT3 to the nucleus is independent of tyrosine phosphorylation. It is postulated that STAT3 is transported to the nucleus with the participation of importin- $\alpha 3$ [59]. According to some authors, STAT1 and STAT3 are transferred to the nucleus with the participation of importin- $\alpha 5$ and importin- $\alpha 7$, and not importin- $\alpha 3$ [60]. It has been shown that STAT proteins can be recirculated, returning to the cytoplasm after their previous phosphatase-mediated dephosphorylation [61].

Studies on the Drosophila model have shown the existence of a non-classical JAK-STAT signalling pathway. They confirmed the presence of nonphosphorylated STAT proteins bound to the het- erochromatin protein 1 (HP1) in the cell nucleus. The activation of STAT by phosphorylation results in the detachment of STAT from HP1, as a result of which HP1 detaches from heterochromatin, disrupting its structure [62]. The non-phosphorylated STAT1, STAT3, STAT5 proteins can also move between the cytoplasm and the cell nucleus without the participation of transport proteins and cellular energy transfer processes [63]. Non-phosphorylated STAT proteins affect gene transcription in a different way than phosphorylated STAT proteins. They bind to specific DNA sequences as monomers [64]. It has been postulated that they play an important role in type 1 interferon-initiated cell signalling, transcription and mRNA translation of interferon target genes [65].

\section{JAK2 gene mutations}

JAK2 $\mathrm{V} 617 \mathrm{~F}$ is the most common mutation in the Philadelphia negative MPNs. Its presence leads to the abnormal autoinhibition of Janus kinase 2 and the constitutive activation of the JAK-STAT signalling pathway. This mutation is present in over $90 \%$ of PV cases, $35-45 \%$ of ET cases, and $35-45 \%$ of PMF cases. Due to the different picture and clinical course of various $J A K 2 \mathrm{~V} 617 \mathrm{~F}$ positive MPNs, their role and importance in the pathogenesis of this group of diseases are currently being investigated [66]. An attempt at answering this question is the theory of the relationship between the content of the mutated allele and the course of the disease process. The variant allele fraction (VAF) expresses the mean content of the pathological variant in the haematopoietic cell population. In most patients with ET, the variant allele fraction is low, namely $25 \%$ or lower. In patients with PV, the content of the abnormal allele is usually high (50\% or higher). The most common defect in the Janus kinase 2 gene is the $J A K 2 \mathrm{~V} 617 \mathrm{~F}$ mutation resulting from a sequence change at position $n t 1849 \mathrm{G} \rightarrow \mathrm{T}$ in exon 14 of the $J A K 2$ gene. Its presence leads to the conversion of valine to phenylalanine within the JAK2 kinase pseudokinase domain sequence. Its occurrence leads to inhibition of the kinase autoinhibition process, which results in constitutive activation of JAK2 kinase, regardless of changes in the conformation of the receptor as a result of interaction with the agonist. Constitutive activation of JAK2 results in excessive JAK-STAT signalling, initiating transcription of target genes involved in the proliferation and differentiation of myeloid precursor cells. The presence of $J A K 2 \mathrm{~V} 617 \mathrm{~F}$ was confirmed in haematopoietic stem cells (HSCs) and myeloid progenitor cells [31, 67-69]. Some 
reports confirm the presence of the mutations also in the cells of the lymphoid lineage [70, 71]. The presence of mutations that interfere with the auto-inhibition of JAK2 kinase leads to an overactivation of the JAK2-STAT signalling pathway via a range of cellular receptors, including the erythropoietin receptor (EPOR), the granulocyte colony-stimulating factor receptor (GCSFR), and the thrombopoietin receptor (myeloproliferative leukaemia protein; MPL). Many data indicate that the heterogeneity of MPN, both in terms of clinical and laboratory manifestation, as well as a different clinical course, is the result of the coexistence of other defects, modifying the course of the disease in individual cases. The clinical manifestation of the disease also appears to include the sequence of "acquiring" specific genetic defects by proliferating bone marrow stem cells, as well as the presence of germline defects preceding the transformation $[72,73]$.

Exon 12 mutations in the $J A K 2$ gene also play an important role in the pathogenesis of MPNPh-. Their presence also disrupts the JAK2 kinase autoinhibition process. Most defects lead to amino acid substitutions within positions 536-547. Contrary to the JAK2 $\mathrm{V} 617 \mathrm{~F}$ mutation, their occurrence was described only in patients with PV (approx. $3 \%$ ). Therefore, testing for their presence should be limited to patients who meet the PV criteria who are JAK2 V617F negative [74], and occasionally in patients with primary myelofibrosis [75]. In patients with the mutation present within exon 12 of the JAK2 gene, the leukocyte and platelet counts are lower, as compared to patients with the JAK2 V617F mutation. This suggests that in PV patients, the presence of mutations within exon 12 leads to increased proliferation of erythroid precursors only. The mechanism of this phenomenon is unknown [76].

\section{Genetic defects with the presence of JAK2 and lymphoproliferative neoplasms}

One of the manifestations of neoplastic transformation of lymphocyte cells in patients with malignant non-Hodgkin's lymphoma is the presence of gene mutations of the proteins in the JAK-STAT signalling pathway. Interestingly, their occurrence is typical of T-cell lymphomas. Thus, in patients with cutaneous T-cell lymphomas, several genetic aberrations involving the JAK1, JAK3, STAT3 and $S T A T 5 B$ genes have been described, significantly altering the JAK-STAT pathway of cell signalling. These include both auto-activating point mutations and fusion genes involving Janus kinases. So far, the presence of JAK1, JAK2 and JAK3 mutations has been confirmed in patients with acute lymphoblastic leukaemia. In adult patients with T-ALL, their frequency was estimated at $16 \%$ [77].

The presence of the JAK1 gene mutation has been confirmed sporadically, most often in people carrying $J A K 3$ or $I L 7 R$ defects. Interestingly, these mutations were heterozygous in nature and concerned the regions coding for the FERM, SH2, pseudokinase and kinase domains [77].

Another typical example of the first group of disorders is the mutations of the Janus 2 kinase gene leading to amino acid changes at position R683 (R683S, R683G and R683E). Their presence leads to a decrease in the stability of the JAK2 protein with a simultaneous significant increase in the kinase activity [78].

A typical example of a fusion defect is described in the case of a CD4 positive T-cell lymphoma $\mathrm{t}(9 ; 13 ; 16)(\mathrm{p} 24 ; \mathrm{q} 34 ; \mathrm{p} 11)$ leading to the formation of the ATXN2L-JAK2 fusion gene and a chimeric ATXN2L-JAK2 protein responsible for constitutive signalling downstream along the JAK-STAT pathway [79]. Another example of changes affecting cell signalling via the JAK-STAT pathway is the confirmation of the presence of the STAT3-JAK2 fusion gene resulting from $t(9 ; 17)$ (p24.1;q21.2) in 4 out of 5 patients with CD4 positive indolent T-cell lymphoproliferative disorder of the gastrointestinal tract (GI TLPD) [80].

\section{STAT gene mutations}

The presence of mutations of genes encoding proteins from the STAT family may lead to the loss of function or its duration, regardless of the gain of function. So far, the presence of the STAT mutation has been confirmed mainly in patients with lymphoproliferative diseases. Most often they concern the sequences coding the SH2 domains of STAT3 and STAT5 genes and are of gain-of-function character. In individual cases, the presence of mutations of the mentioned genes within the DNA binding domain and the coiled-coil domain was confirmed. Their detailed overview is presented in Figure 4 [81]. The most common of these defects is the STAT5B N642H mutation. Its presence has been confirmed in peripheral T-cell_lymphoma (PTLC) $[82,83-85]$. The presence of the defect stabilizes the formed STAT dimer which leads to an increase in the number of phosphorylated tyrosines and hyperactivation of STAT5B [86]. The reason for starting the research on the role of STAT protein 


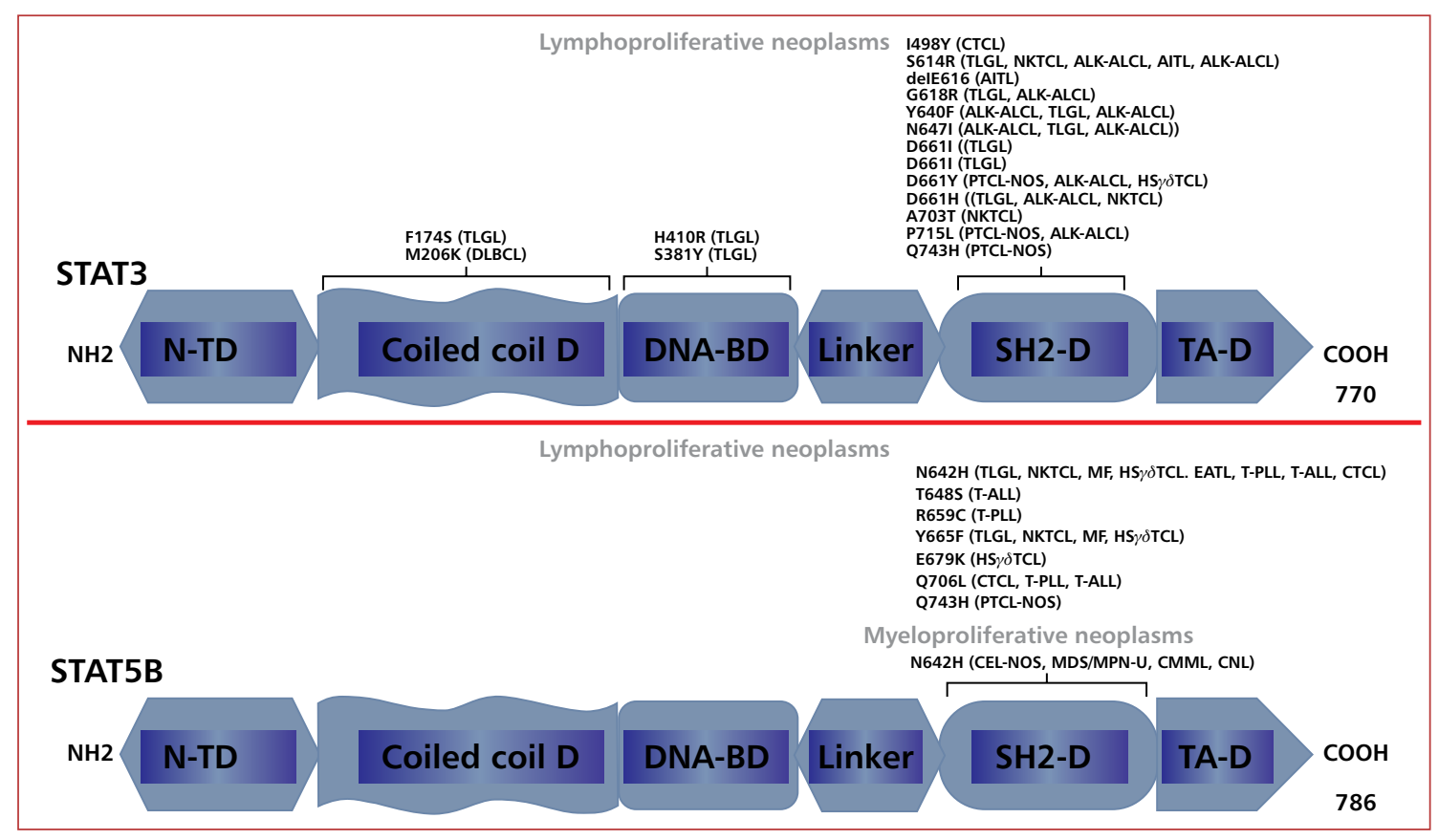

Figure 4. The most common location of STAT3 and STAT5B mutations in patients with lymphoid and myeloid neoplasms (acc. to [81]). Explanation of the abbreviations used: N-TD - NH2 terminal domain; coiled-coil; D - coiled-coil domain; DNA-BD - DNA binding domain; SH2-D - Scr homology domain 2; TAD — transactivation domain; TLGL — T-cell large granular lymphocytic leukaemia; CTCL — cutaneous T-cell lymphoma; NKTCL — natural killer/T-cell lymphoma; ALK-ALCL — ALK-negative anaplastic large cell lymphoma; HS $\gamma \delta \mathrm{TCL}$ - hepatosplenic T-cell lymphoma $\gamma \delta$; PTCL-NOS — peripheral T-cell lymphoma, not elsewhere classified, MF — mycosis fungoides; GF granuloma fungoides; EATL — enteropathy-associated T-cell lymphoma; T-PLL — T-cell prolymphocytic leukaemia; T-ALL — T-cell acute lymphoblastic leukaemia; DLBCL — diffuse large B-cell lymphoma; CEL-NOS — chronic eosinophilic leukaemia not otherwise specified; MDS/MPN-U — myelodysplastic/myeloproliferative neoplasms unclassified; $\mathrm{CMML}$ - chronic myelomonocytic leukaemia; CNL — chronic neutrophilic leukaemia

defects in oncogenesis was to demonstrate the constitutive activity of STAT1, STAT3 and STAT5 in acute myeloid leukaemia cells [87, 88]. It also turned out that constitutive activation of STAT1 plays a key role in promoting the growth of leukaemic cells, and STAT5 in myeloid or lymphoid differentiation of leukaemic cells [89]. In the latter case, the presence of the STAT5A mutation leads to the formation and cellular accumulation of a stable tetramer as a consequence of the development of multilineage leukaemia [90]. Ser725 and Ser779, which are the phosphorylation sites of the STAT5A protein, seem to play a key role in this process [91]. The N-terminal fragment of STAT5A/B seems to play a similar role in the neoplastic transformation of B lymphocytes [92]. According to current data, STAT5A and STAT5B act as proto-oncogenes, participating in the processes of regulation of HSC proliferation and survival [93, 94]. STAT5A and STAT5B promote the transcription of many anti-apoptotic genes (Mcl-1, Bcl-2, Bcl-xl), D-type cyclins (D1, D2 and D3), receptor protein chains and cytokines [93, 95-97].

However, it is worth remembering that the activation of STAT5A/B may also be the result of excessive activity of upstream mutant tyrosine kinases, including JAK2 V617F, BCR-ABL, FLT3-ITD, and KIT D816V [100].

\section{STAT gene mutations}

in lymphoproliferative neoplasms

In the case of the STAT3 gene, the described defects lead to an increase in the gain of function. The presence of the STAT3 mutation has been confirmed in T-LGL leukaemia, chronic NK lymphoproliferative disorder (CLPD-NK) and ALK-negative anaplastic large cell lymphoma [99, 100]. The STAT5A and STAT5B proteins participate in the activation of the transcription of anti-apoptotic genes. The STAT5A/B overexpression may contribute to the disruption of the natural mechanisms of programmed cell death [81]. 
It is postulated that STAT5 mutations may be solely responsible for the neoplastic transformation of defective cells $[93,100,101]$. Autoactivating molecular defects concerns the $S T A T 5 B$ gene much more often than STAT5A. The cause of this phenomenon is unknown. Most of them are located within the SH2 STAT5B domain coding sequence. Their presence leads to the stabilization of the dimer form of STAT proteins [102]. The presence of $S T A T 5 B$ defects has been confirmed in NK cell/T-lymphocyte neoplasms [86], as well as in various forms of peripheral $\mathrm{T}$ cell lymphomas [103]. One of the recently published studies on the driver mutation confirmed the key importance of the STAT6 mutation also in patients with B-cell lymphoma. Their occurrence was confirmed using an integrated whole-genome analysis [104]. Mutations in the STAT3, STAT5B, JAK1, JAK2, and PTPN1 genes have also been documented in patients with classic Hodgkin's disease, affecting cell signalling via the JAK-STAT pathway. Mutations of the gene encoding the STAT6 protein, present in approximately $1 / 3$ of patients, functionally related to SOCS1, the main inhibitor of JAK-STAT signalling, seem to be of particular importance in this regard [105].

\section{Defects involving STAT genes \\ in myeloproliferative neoplasms}

In recent years, data confirming the potential importance of the presence of STAT gene mutations also in the pathogenesis of MPN have been presented. Current data confirmed the activation of the JAK-STAT pathway in patients with chronic myeloid leukaemia and MPNPh- as a result of the presence of defects other than STAT gene defects. In the first case, excessive activation of the JAKSTAT pathway is the result of mainly constitutive activation of the BCR-ABL tyrosine kinase. In the case of MPNPh-, the STAT over-expression is the result of the presence of mutations in the JAK2 genes that reduce the auto-inhibition of the kinase, mutations in the $M P N$ gene responsible for autoactivation of the MPL receptor, or mutations in the calreticulin $(C A L R)$ gene leading to a change in the location of the CALR protein and the formation of the auto-activating MPL receptor protein complex. However, the occurrence of STAT5B N642H mutations associated with eosinophilia in MPNs [chronic eosinophilic leukaemia not elsewhere specified (CEL-NOS), hypereosinophilic syndrome] has been reported recently. The presence of this mutation has also been confirmed in patients with myelodysplastic syndrome/unclassified MPN
(MDS/MPN-U), atypical form of chronic myeloid leukaemia (aCML) and chronic myelomonocytic leukaemia (CMML) [82]. The presence of the STAT5B N642H mutation was also confirmed in a patient with chronic neutrophilic leukaemia with progressively increasing leukocytosis and severe infectious complications. In the described case, its occurrence was accompanied by the presence of CSF3RT618I, ASXL1G942 fs defects [85].

\section{Other gene defects responsible for the disruption of JAK-STAT signalling in patients with lympho- and myeloproliferative neoplasms}

\section{IL-7 receptor mutations alpha}

Most of the described defects of the gene encoding the IL-7 subunit $\alpha$ of the IL-7 receptor are auto-activating mutations. Their presence has been confirmed in approximately $19 \%$ of patients with T-ALL and $2-3 \%$ of patients with the precursor form of B-ALL [106-111].

\section{CRLF2 receptor mutations}

One of the described defects of the CRLF2 gene is the gain-of-function type Phe232Cys mutation. Its presence leads to receptor dimerization and cytokine-independent proliferation of defective cells [112, 113].

\section{Calreticulin gene mutations}

For the first time, the presence of mutations within $C A L R$ was independently confirmed by Klampf et al. and Nangalia et al. in 2013 [114, 115]. CALR is a protein with a pleiotropic function, 46 $\mathrm{kDa}$ in size. The cellular location of calreticulin is the endoplasmic reticulum. Its presence has also been confirmed in the cytosol and the cell nucleus. The main biological function of CALR is the binding of calcium ions in the endoplasmic reticulum (ER) of muscle cells, in which it also plays a regulatory role in the process of muscle contraction [116]. Other functions of CALR include regulation of calcium-dependent cell signalling, electrical conductivity, cell differentiation and division, as well as the processes of adhesion and apoptosis. The CALR structure consists of 3 domains: $N$-terminal globular domain, proline-rich domain (P domain) and highly negatively charged $\mathrm{C}$-terminal domain. The proline-rich domain and the $\mathrm{C}$-terminal domain are mainly involved in the binding of proteins to calcium ions. While the $\mathrm{N}$-terminal domain, together with the proline-rich domain, performs chaperone functions due to their proximity which enables 
interaction with glycosylated and non-glycosylated proteins [117]. They are responsible for the quality control of the folding of most of the produced proteins in the lumen of the endoplasmic reticulum. A disruption of this process may be important in the pathogenesis of the Philadelphia negative MPNs. The specific KDEL amino acid sequence present within the $\mathrm{C}$-terminal domain is responsible for the correct localization of the CALR protein in the ER lumen (protein retention due to the correct sequence of the localization domain) $[118,119]$.

The incidence of CALR gene defects in patients with ET is $25 \%$, and in patients with PMF it is $35 \%$ [115]. Mutations of the CALR gene in patients with $\mathrm{MPNPh}$ - take the form of insertions or deletions located within exon 9 of the CALR gene, at the end of the coding sequence from the 3 ' side. Their occurrence leads to a change of the reading frame within the 3 -terminal codons by -1 or +2 . The genetic changes result in the replacement of the KDEL motif (ER retention signal) on the $\mathrm{C}$-terminal part of the protein with a different mutant amino acid sequence [114, 115]. The two most common types of molecular defects in the CALR gene are a 52-nucleotide deletion (del52, a type-I mutation) and a 5-nucleotide insertion (ins5, a type-II mutation) [66]. The presence of the CALR gene mutation, as well as the JAK2 and $M P L$ gene defects, leads to the transformation of the malignant myeloid stem cell and its excessive proliferation as a result of the activation of the JAK-STAT pathway. Presently, the mechanism of aberrant JAK-STAT pathway activation in these cases has been described. It postulates the formation of the CALRmut-MPL protein complex already within the $\mathrm{ER}$, with the subsequent placement of the complex in the cell membrane of the precursor cells already in the form with the originally activated MPL receptor [120]. The proposed mechanism for activating the JAK-STAT pathway was confirmed by laboratory tests. These studies demonstrated the activating properties of the mutant CALR protein on MPL, resembling that of a natural agonist. The activity of the CALRmut protein is MPL dependent, as both the activation of STAT5 induced by both CALR mutants and the cytokine-dependent growth of $\mathrm{Ba} / \mathrm{F} 3$ cells require the presence of MPL [121]. The presented mechanisms of MPL-CALR interactions explain why mutations of the $C A L R$ gene lead to disease symptoms only in patients with ET and PMF. This phenomenon is the result of the possible occurrence of the described interactions only in progenitor cells of the megakaryocytic lineage expressing MPL.
Thrombopoietin receptor

gene mutations (MPL)

Under physiological conditions, $M P L$ plays a key role in the regulation of thrombopoietinmediated megakaryopoiesis. The TPO-dependent activity of $M P L$ enables the maintenance of a constant pool of megakaryopoietic progenitor cells in a feedback mechanism $[122,123]$. The importance of the proper functioning of the MPL-TPO interaction is confirmed by clinical observations made in patients with thrombocytopenia and/or bone marrow failure due to the presence of TPO or MPL defects $[124,125]$. MPL is expressed in haematopoietic stem cells and cells of the platelet-forming lineage. MPL is not necessary for the development of other cell lines [126].

The MPL protein belongs to the type I family of integrin receptors. Its ligand is thrombopoietin [127, 128]. MPL consists of 3 domains. The extracellular domain is made of two cytokine receptors. Each of them has two fibronectin type III-like domains [129]. The extracellular domain is responsible for the binding of thrombopoietin. The transmembrane domain is essential for anchoring the receptor to the membrane. The role of the intracellular domain is signalling by JAK2 kinases. This domain contains two box motifs that are responsible for the binding of JAK tyrosine kinases. MPL is present on the cell surface as a monomer or an unstable dimer $[128,129]$.

The presence of a mutation in the $M P L$ gene encoding the receptor for thrombopoietin was confirmed in $5 \%$ of primary bone marrow fibrosis and $1 \%$ of essential thrombocythemia patients. Their presence, as in the case of the JAK2 V617F mutation, leads to cytokine-independent activation of the JAK-STAT pathway. The most common mutations in the $M P L$ gene in patients with $\mathrm{MPNPh}$ - are those located within the W515L/R hotspot. In individual cases, the presence of other mutations, including W515A/G has also been described [130]. Most of the described defects in the $M P L$ gene were identified within exon 10 which encodes the receptor's transmembrane domain [131]. Their presence leads to constitutive activation of the receptor without the participation of an agonist, and thus the thrombopoietin receptor-JAK-STAT signalling pathway [132, 133]. The importance of the presence of defects located at position 505 in patients with MPNPhis currently under evaluation. Their occurrence has been described in both familial and neoplastic thrombocythemia [132]. 


\section{Molecularly targeted therapy and mutations of JAK and STAT genes}

The use of Janus 2 kinase inhibitors (ruxolitinib, fedratinib) in the therapy of Philadelphia negative myeloproliferative neoplasms is currently the standard treatment for this group of diseases. Interestingly, the therapeutic effect of reducing the severity of cytokine symptoms and splenomegaly is obtained regardless of the presence of the JAK2 gene mutation. This phenomenon is explained by the inhibition of excessive activation of the JAKSTAT signalling pathway in patients with MPNPh-, irrespective of the presence of the Janus kinase 2 defect.

Experience with the use of JAK inhibitors is at an early stage in clinical trials. In an ongoing phase 2 clinical trial (CELTIC-1, NCT0402108), the overall response rate was assessed as 38\% [134] in patients with relapsed refractory PTCL. Cerdulatinib, a competitive inhibitor of the SYK and JAK family kinases, is at a similar stage of Phase $2 \mathrm{~A}$ research. In the evaluation of 38 patients with resistant PTCL and 22 patients with CTCL, the response rate was 35\% [135]. Another drug also evaluated in Phase 2 clinical trials (NCT 03598959) in patients with extranodal natural killer/T-cell lymphoma (ENKTCL) is Tofacitinib (a JAK3 inhibitor) [136]. A molecule that may find potential application in the treatment of NK/T-cell lymphomas is a selective JAK3 inhibitor defined by the acronym PRN371. It exhibits potent inhibitory activity against JAK3 by binding to Cys909 at the ATP binding site [137]. Experimental studies evaluating the effect of JAKSTAT inhibitors on $\gamma / \delta$ T lymphoma cells are also at the preliminary phase [138].

\section{Summary}

The presence of genetic defects within genes encoding components of the JAK-STAT signalling pathway is one of the basic mechanisms leading to the transformation of neoplastic precursor cells of lympho- and myelopoiesis. Currently, the assessment of the presence of JAK2 gene mutations is a standard in the diagnosis of myeloproliferative neoplasms. Perhaps the assessment of mutations of other JAK and STAT genes will soon become a standard for the assessment of lympho- and myeloproliferative neoplasms, and the confirmation of their presence will be a requirement (criterion) for the diagnosis of their specific form. Demonstrating the presence of the mutations within the $J A K$ or STAT genes will probably also change the therapeutic approach in neoplastic lympho- and myeloproliferative diseases in the nearest future, with the increasing use of inhibitors of the Janus family kinases and STAT proteins.

\section{Acknowledgements}

The paper was written as a part of the course "Introduction to scientific research" during fulltime studies in the second year of studies at the Medical Faculty of Poznan University of Medical Sciences in the academic year 2019/2020.

The authors would like to thank Katarzyna Lewandowska for editing and proofreading the final version of the manuscript.

\section{Conflict of interest}

None.

\section{Funding}

None.

\section{References}

1. Ceredig R, Rolink AG, Brown G. Models of haematopoiesis: seeing the wood for the trees. Nat Rev Immunol. 2009; 9(4): 293-300, doi: 10.1038/nri2525, indexed in Pubmed: 19282853.

2. Calvi LM, Adams GB, Weibrecht KW, et al. Osteoblastic cells regulate the haematopoietic stem cell niche. Nature. 2003; 425(6960): 841-846, doi: 10.1038/nature02040, indexed in Pubmed: 14574413 .

3. Méndez-Ferrer S, Michurina TV, Ferraro F, et al. Mesenchymal and haematopoietic stem cells form a unique bone marrow niche. Nature. 2010; 466(7308): 829-834, doi: 10.1038/nature09262, indexed in Pubmed: 20703299.

4. Sugiyama T, Kohara H, Noda M, et al. Maintenance of the hematopoietic stem cell pool by CXCL12-CXCR4 chemokine signaling in bone marrow stromal cell niches. Immunity. 2006; 25(6): 977-988, doi: 10.1016/j.immuni.2006.10.016, indexed in Pubmed: 17174120.

5. Wang LD, Wagers AJ. Dynamic niches in the origination and differentiation of haematopoietic stem cells. Nat Rev Mol Cell Biol. 2011; 12(10): 643-655, doi: 10.1038/nrm3184, indexed in Pubmed: 21886187.

6. Cedar H, Bergman Y. Epigenetics of haematopoietic cell development. Nat Rev Immunol. 2011; 11(7): 478-488, doi: 10.1038/ nri2991, indexed in Pubmed: 21660052.

7. Rosenbauer F, Tenen DG. Transcription factors in myeloid development: balancing differentiation with transformation. Nat Rev Immunol. 2007; 7(2): 105-117, doi: 10.1038/nri2024, indexed in Pubmed: 17259967.

8. Ramírez J, Lukin K, Hagman J. From hematopoietic progenitors to B cells: mechanisms of lineage restriction and commitment. Curr Opin Immunol. 2010; 22(2): 177-184, doi: 10.1016/j. coi.2010.02.003, indexed in Pubmed: 20207529. 
9. Mazzucchelli R, Durum SK. Interleukin-7 receptor expression: intelligent design. Nat Rev Immunol. 2007; 7(2): 144-154, doi: 10.1038/nri2023, indexed in Pubmed: 17259970.

10. Barata JT, Silva A, Brandao JG, et al. Activation of PI3K is indispensable for interleukin 7-mediated viability, proliferation, glucose use, and growth of $\mathrm{T}$ cell acute lymphoblastic leukemia cells. J Exp Med. 2004; 200(5): 659-669, doi: 10.1084/jem.20040789, indexed in Pubmed: 15353558.

11. Canté-Barrett K, Spijkers-Hagelstein JAP, Buijs-Gladdines JG, et al. MEK and PI3K-AKT inhibitors synergistically block activated IL7 receptor signaling in T-cell acute lymphoblastic leukemia. Leukemia. 2016; 30(9): 1832-1843, doi: 10.1038/leu.2016.83, indexed in Pubmed: 27174491.

12. Lodewijckx I, Cools J. Deregulation of the interleukin-7 signaling pathway in lymphoid malignancies. Pharmaceuticals (Basel). 2021; 14(5), doi: 10.3390/ph14050443, indexed in Pubmed: 34066732.

13. Metcalf D. Hematopoietic cytokines. Blood. 2008; 111(2): 485-491, doi: 10.1182/blood-2007-03-079681, indexed in Pubmed: 18182579.

14. Morris R, Kershaw NJ, Babon JJ. The molecular details of cytokine signaling via the JAK/STAT pathway. Protein Sci. 2018; 27(12): 1984-2009, doi: 10.1002/pro.3519, indexed in Pubmed: 30267440.

15. Gilliland DG, Griffin JD. The roles of FLT3 in hematopoiesis and leukemia. Blood. 2002; 100(5): 1532-1542, doi: 10.1182/ blood-2002-02-0492, indexed in Pubmed: 12176867.

16. Broudy VC, Lin NL, Kaminski WE, et al. Isolation and characterization of a monoclonal antibody that recognizes the human c-kit receptor. Blood. 1992; 79(2): 338-346, indexed in Pubmed: 1370384 .

17. Rönnstrand L. Signal transduction via the stem cell factor receptor/c-Kit. Cell Mol Life Sci. 2004; 61(19-20): 2535-2548, doi: 10.1007/s00018-004-4189-6, indexed in Pubmed: 15526160.

18. Baker SJ, Rane SG, Reddy EP. Hematopoietic cytokine receptor signaling. Oncogene. 2007; 26(47): 6724-6737, doi: 10.1038/ sj.onc.1210757, indexed in Pubmed: 17934481.

19. Jatiani SS, Baker SJ, Silverman LR, et al. Jak/STAT pathways in cytokine signaling and myeloproliferative disorders: approaches for targeted therapies. Genes Cancer. 2010; 1(10): 979-993, doi: 10.1177/1947601910397187, indexed in Pubmed: 21442038.

20. Schindler C, Levy DE, Decker T. JAK-STAT signaling: from interferons to cytokines. J Biol Chem. 2007; 282(28): 20059-20063, doi: 10.1074/jbc.R700016200, indexed in Pubmed: 17502367.

21. Khwaja A. The role of Janus kinases in haemopoiesis and haematological malignancy. Br J Haematol. 2006; 134(4): 366-384, doi: 10.1111/j.1365-2141.2006.06206.x, indexed in Pubmed: 16822289.

22. Okay M, Haznedaroglu IC. Protein kinases in hematological disorders. Adv Exp Med Biol. 2021; 1275: 383-393, doi: 10.1007/9783-030-49844-3_15, indexed in Pubmed: 33539024.

23. Funakoshi-Tago M, Tago K, Kasahara T, et al. Negative regulation of Jak2 by its auto-phosphorylation at tyrosine 913 via the Epo signaling pathway. Cell Signal. 2008; 20(11): 1995-2001, doi: 10.1016/j.cellsig.2008.07.008, indexed in Pubmed: 18682290.

24. Wilks AF, Harpur AG, Kurban RR, et al. Two novel protein-tyrosine kinases, each with a second phosphotransferase-related catalytic domain, define a new class of protein kinase. Mol Cell Biol. 1991; 11(4): 2057-2065, doi: 10.1128/mcb.11.4.2057-2065.1991, indexed in Pubmed: 1848670.

25. Feng J, Witthuhn BA, Matsuda T, et al. Activation of Jak2 catalytic activity requires phosphorylation of Y1007 in the kinase activa- tion loop. Mol Cell Biol. 1997; 17(5): 2497-2501, doi: 10.1128/ MCB.17.5.2497, indexed in Pubmed: 9111318.

26. Liu KD, Gaffen SL, Goldsmith MA, et al. Janus kinases in interleukin-2-mediated signaling: JAK1 and JAK3 are differentially regulated by tyrosine phosphorylation. Curr Biol. 1997; 7(11): 817-826, doi: 10.1016/s0960-9822(06)00369-1, indexed in Pubmed: 9382798.

27. Saharinen P, Takaluoma K, Silvennoinen O. Regulation of the Jak2 tyrosine kinase by its pseudokinase domain. Mol Cell Biol. 2000; 20(10): 3387-3395, doi: 10.1128/MCB.20.10.3387-3395.2000, indexed in Pubmed: 10779328.

28. Lindauer K, Loerting T, Liedl KR, et al. Prediction of the structure of human Janus kinase 2 (JAK2) comprising the two carboxyterminal domains reveals a mechanism for autoregulation. Protein Eng. 2001; 14(1): 27-37, doi: 10.1093/protein/14.1.27, indexed in Pubmed: 11287676.

29. Saharinen P, Silvennoinen O. The pseudokinase domain is required for suppression of basal activity of Jak2 and Jak3 tyrosine kinases and for cytokine-inducible activation of signal transduction. J Biol Chem. 2002; 277(49): 47954-47963, doi: 10.1074/jbc. M205156200, indexed in Pubmed: 12351625.

30. Saharinen P, Vihinen M, Silvennoinen O. Autoinhibition of Jak2 tyrosine kinase is dependent on specific regions in its pseudokinase domain. Mol Biol Cell. 2003; 14(4): 1448-1459, doi: 10.1091/mbc. e02-06-0342, indexed in Pubmed: 12686600.

31. Xu P, Shen P, Yu B, et al. Janus kinases (JAKs): the efficient therapeutic targets for autoimmune diseases and myeloproliferative disorders. Eur J Med Chem. 2020; 192: 112155, doi: 10.1016/j. ejmech.2020.112155, indexed in Pubmed: 32120325.

32. Kralovics R, Passamonti F, Buser AS, et al. A gain-of-function mutation of JAK2 in myeloproliferative disorders. $\mathrm{N}$ Engl J Med. 2005; 352(17): 1779-1790, doi: 10.1056/NEJMoa051113, indexed in Pubmed: 15858187.

33. Fasouli ES, Katsantoni E. JAK-STAT in early hematopoiesis and leukemia. Front Cell Dev Biol. 2021; 9: 669363, doi: 10.3389/ fcell.2021.669363, indexed in Pubmed: 34055801.

34. Bousoik E, Montazeri Aliabadi H. "Do we know Jack" About JAK? A closer look at JAK/STAT signaling pathway. Front Oncol. 2018; 8: 287, doi: 10.3389/fonc.2018.00287, indexed in Pubmed: 30109213.

35. Wang Z, Bunting KD. STAT5 in hematopoietic stem cell biology and transplantation. JAKSTAT. 2013; 2(4): e27159, doi: 10.4161/ jkst.27159, indexed in Pubmed: 24498540.

36. Kleppe M, Spitzer MH, Li S, et al. Jak1 integrates cytokine sensing to regulate hematopoietic stem cell function and stress hematopoiesis. Cell Stem Cell. 2017; 21(4): 489-501.e7, doi: 10.1016/j. stem.2017.08.011, indexed in Pubmed: 28965767.

37. Neubauer H, Cumano A, Müller M, et al. Jak2 deficiency defines an essential developmental checkpoint in definitive hematopoiesis. Cell. 1998; 93(3): 397-409, doi: 10.1016/s00928674(00)81168-x, indexed in Pubmed: 9590174.

38. Parganas E, Wang D, Stravopodis D, et al. Jak2 is essential for signaling through a variety of cytokine receptors. Cell. 1998; 93(3): 385-395, doi: 10.1016/s0092-8674(00)81167-8, indexed in Pubmed: 9590173.

39. Aaronson DS, Horvath CM. A road map for those who don't know JAK-STAT. Science. 2002; 296(5573): 1653-1655, doi: 10.1126/ science.1071545, indexed in Pubmed: 12040185.

40. Copeland NG, Gilbert DJ, Schindler C, et al. Distribution of the mammalian Stat gene family in mouse chromosomes. Genomics. 1995; 29(1): 225-228, doi: 10.1006/geno.1995.1235, indexed in Pubmed: 8530075 . 
41. Vinkemeier U, Moarefi I, Darnell JE, et al. Structure of the aminoterminal protein interaction domain of STAT-4. Science. 1998; 279(5353): 1048-1052, doi: 10.1126/science.279.5353.1048, indexed in Pubmed: 9461439.

42. Chen X, Vinkemeier U, Zhao Y, et al. Crystal structure of a tyrosine phosphorylated STAT-1 dimer bound to DNA. Cell. 1998; 93(5): 827-839, doi: 10.1016/s0092-8674(00)81443-9, indexed in Pubmed: 9630226 .

43. Lee CK, Smith E, Gimeno R, et al. STAT1 affects lymphocyte survival and proliferation partially independent of its role downstream of IFN-gamma. J Immunol. 2000; 164(3): 1286-1292, doi: 10.4049/jimmunol.164.3.1286, indexed in Pubmed: 10640742.

44. Boisson-Dupuis S, Kong XF, Okada S, et al. Inborn errors of human STAT1: allelic heterogeneity governs the diversity of immunological and infectious phenotypes. Curr Opin Immunol. 2012; 24(4): 364-378, doi: 10.1016/j.coi.2012.04.011, indexed in Pubmed: 22651901.

45. Bhattacharya S, Eckner R, Grossman S, et al. Cooperation of Stat2 and p300/CBP in signalling induced by interferon-alpha. Nature. 1996; 383(6598): 344-347, doi: 10.1038/383344a0, indexed in Pubmed: 8848048.

46. Dasgupta M, Dermawan JK, Willard B, et al. STAT3-driven transcription depends upon the dimethylation of K49 by EZH2. Proc Natl Acad Sci USA. 2015; 112(13): 3985-3990, doi: 10.1073/pnas. 1503152112, indexed in Pubmed: 25767098.

47. Ma X, Nakayamada S, Kubo S, et al. Expansion of T follicular helper-T helper 1 like cells through epigenetic regulation by signal transducer and activator of transcription factors. Ann Rheum Dis. 2018; 77(9): 1354-1361, doi: 10.1136/annrheumdis-2017-212652, indexed in Pubmed: 29853448.

48. Kane A, Deenick EK, Ma CS, et al. STAT3 is a central regulator of lymphocyte differentiation and function. Curr Opin Immunol. 2014; 28: 49-57, doi: 10.1016/j.coi.2014.01.015, indexed in Pubmed: 24594518 .

49. Teng TS, Lin B, Manser Ed, et al. Stat3 promotes directional cell migration by regulating Rac1 activity via its activator betaPIX. J Cell Sci. 2009; 122(Pt 22): 4150-4159, doi: 10.1242/jcs.057109, indexed in Pubmed: 19861492.

50. Agnello D, Lankford CSR, Bream J, et al. Cytokines and transcription factors that regulate $\mathrm{T}$ helper cell differentiation: new players and new insights. J Clin Immunol. 2003; 23(3): 147-161, doi: 10.1023/a:1023381027062, indexed in Pubmed: 12797537.

51. Kaplan MH. STAT4: a critical regulator of inflammation in vivo. Immunol Res. 2005; 31(3): 231-242, doi: 10.1385/IR:31:3:231, indexed in Pubmed: 15888914.

52. Nosaka T, Kawashima T, Misawa K, et al. STAT5 as a molecular regulator of proliferation, differentiation and apoptosis in hematopoietic cells. EMBO J. 1999; 18(17): 4754-4765, doi: 10.1093/ emboj/18.17.4754, indexed in Pubmed: 10469654.

53. Karpathiou G, Papoudou-Bai A, Ferrand E, et al. STAT6: A review of a signaling pathway implicated in various diseases with a special emphasis in its usefulness in pathology. Pathol Res Pract. 2021; 223: 153477, doi: 10.1016/j.prp.2021.153477, indexed in Pubmed: 33991851.

54. Shuai K, Stark GR, Kerr IM, et al. A single phosphotyrosine residue of Stat91 required for gene activation by interferon-gamma. Science. 1993; 261(5129): 1744-1746, doi: 10.1126/science.7690989, indexed in Pubmed: 7690989.

55. Ihle JN, Ihle JN, Nosaka T, et al. The Janus protein tyrosine kinase family and its role in cytokine signaling. Adv Immunol. 1995; 60(2): 1-35, doi: 10.1016/s0065-2776(08)60582-9, indexed in Pubmed: 8607368.
56. Levy DE, Darnell JE. Stats: transcriptional control and biological impact. Nat Rev Mol Cell Biol. 2002; 3(9): 651-662, doi: 10.1038/ nrm909, indexed in Pubmed: 12209125.

57. Fagerlund R, Mélen K, Kinnunen L, et al. Arginine/lysinerich nuclear localization signals mediate interactions between dimeric STATs and importin alpha 5. J Biol Chem. 2002; 277(33): 30072-30078, doi: 10.1074/jbc.M202943200, indexed in Pubmed: 12048190.

58. McBride KM, Banninger G, McDonald C, et al. Regulated nuclear import of the STAT1 transcription factor by direct binding of importin-alpha. EMBO J. 2002; 21(7): 1754-1763, doi: 10.1093/ emboj/21.7.1754, indexed in Pubmed: 11927559.

59. Liu L, McBride KM, Reich NC. STAT3 nuclear import is independent of tyrosine phosphorylation and mediated by importinalpha3. Proc Natl Acad Sci USA. 2005; 102(23): 8150-8155, doi: 10.1073/pnas.0501643102, indexed in Pubmed: 15919823.

60. Ma J, Cao X. Regulation of Stat3 nuclear import by importin alpha5 and importin alpha7 via two different functional sequence elements. Cell Signal. 2006; 18(8): 1117-1126, doi: 10.1016/j. cellsig.2005.06.016, indexed in Pubmed: 16298512.

61. Haspel RL, Darnell JE. A nuclear protein tyrosine phosphatase is required for the inactivation of Stat1. Proc Natl Acad Sci USA. 1999; 96(18): 10188-10193, doi: 10.1073/pnas.96.18.10188, indexed in Pubmed: 10468584.

62. Shi S, Larson K, Guo D, et al. Drosophila STAT is required for directly maintaining HP1 localization and heterochromatin stability. Nat Cell Biol. 2008; 10(4): 489-496, doi: 10.1038/ncb1713, indexed in Pubmed: 18344984.

63. Vinkemeier U. Getting the message across, STAT! Design principles of a molecular signaling circuit. J Cell Biol. 2004; 167(2): 197-201, doi: 10.1083/jcb.200407163, indexed in Pubmed: 15504906.

64. Yang J, Stark GR. Roles of unphosphorylated STATs in signaling. Cell Res. 2008; 18(4): 443-451, doi: 10.1038/cr.2008.41, indexed in Pubmed: 18364677.

65. Mazewski C, Perez RE, Fish EN, et al. Type I interferon (IFN)-regulated activation of canonical and non-canonical signaling pathways. Front Immunol. 2020; 11: 606456, doi: 10.3389/fimmu.2020.606456, indexed in Pubmed: 33329603.

66. Jia R, Kralovics R. Progress in elucidation of molecular pathophysiology of myeloproliferative neoplasms and its application to therapeutic decisions. Int J Hematol. 2020; 111(2): 182-191, doi: 10.1007/s12185-019-02778-9, indexed in Pubmed: 31741139.

67. James C, Ugo V, Couédic JPLe, et al. A unique clonal JAK2 mutation leading to constitutive signalling causes polycythaemia vera. Nature. 2005; 434(7037): 1144-1148, doi: 10.1038/nature03546.

68. Baxter E, Scott L, Campbell P, et al. Acquired mutation of the tyrosine kinase JAK2 in human myeloproliferative disorders. Lancet. 2005; 365(9464): 1054-1061, doi: 10.1016/s01406736(05)71142-9.

69. Levine RL, Wadleigh M, Cools J, et al. Activating mutation in the tyrosine kinase JAK2 in polycythemia vera, essential thrombocythemia, and myeloid metaplasia with myelofibrosis. Cancer Cell. 2005; 7(4): 387-397, doi: 10.1016/j.ccr.2005.03.023, indexed in Pubmed: 15837627.

70. Delhommeau F, Dupont S, Tonetti C, et al. Evidence that the JAK2 G1849T (V617F) mutation occurs in a lymphomyeloid progenitor in polycythemia vera and idiopathic myelofibrosis. Blood. 2007; 109(1): 71-77, doi: 10.1182/blood-2006-03-007146, indexed in Pubmed: 16954506.

71. Ishii T, Bruno E, Hoffman R, et al. Involvement of various hematopoietic-cell lineages by the JAK2V617F mutation in poly- 
cythemia vera. Blood. 2006; 108(9): 3128-3134, doi: 10.1182/ blood-2006-04-017392, indexed in Pubmed: 16757685.

72. O'Sullivan J, Mead AJ. Heterogeneity in myeloproliferative neoplasms: causes and consequences. Adv Biol Regul. 2019; 71: 55-68, doi: 10.1016/j.jbior.2018.11.007, indexed in Pubmed: 30528537.

73. Ortmann CA, Kent D, Nangalia J, et al. Effect of mutation order on myeloproliferative neoplasms. N Engl J Med. 2015; 372(7): 601-612, doi: 10.1056/nejmoa1412098.

74. Scott LM, Tong W, Levine RL, et al. JAK2 exon 12 mutations in polycythemia vera and idiopathic erythrocytosis. N Engl J Med. 2007; 356(5): 459-468, doi: 10.1056/NEJMoa065202, indexed in Pubmed: 17267906.

75. Maddali M, Kulkarni UP, Ravindra N, et al. JAK2 exon 12 mutations in cases with JAK2V617F-negative polycythemia vera and primary myelofibrosis. Ann Hematol. 2020; 99(5): 983-989, doi: 10.1007/s00277-020-04004-7, indexed in Pubmed: 32277273.

76. Passamonti F, Elena C, Schnittger S, et al. Molecular and clinical features of the myeloproliferative neoplasm associated with JAK2 exon 12 mutations. Blood. 2011; 117(10): 2813-2816, doi: 10.1182/blood-2010-11-316810, indexed in Pubmed: 21224469.

77. Flex E, Petrangeli V, Stella L, et al. Somatically acquired JAK1 mutations in adult acute lymphoblastic leukemia. J Exp Med. 2008; 205(4): 751-758, doi: 10.1084/jem.20072182, indexed in Pubmed: 18362173.

78. Li F, Guo HY, Wang M, et al. The effects of R683S (G) genetic mutations on the JAK2 activity, structure and stability. Int J Biol Macromol. 2013; 60: 186-195, doi: 10.1016/j.ijbiomac.2013.05.029, indexed in Pubmed: 23748007.

79. Panagopoulos I, Gorunova L, Spetalen S, et al. FFusion of the genes ataxin 2 like, ATXN2L, and Janus kinase 2, JAK2, in cutaneous CD4 positive T-cell lymphoma. Oncotarget. 2017; 8(61): 103775-103784, doi: 10.18632/oncotarget.21790, indexed in Pubmed: 29262599.

80. Sharma A, Oishi N, Boddicker RL, et al. Recurrent fusions in indolent T-cell lymphoproliferative disorder of the gastrointestinal tract. Blood. 2018; 131(20): 2262-2266, doi: 10.1182/ blood-2018-01-830968, indexed in Pubmed: 29592893.

81. Ariyoshi K, Nosaka T, Yamada K, et al. Constitutive activation of STAT 5 by a point mutation in the SH2 domain. J Biol Chem. 2000; 275(32): 24407-24413, doi: 10.1074/jbc.M909771199, indexed in Pubmed: 10823841.

82. Cross NCP, Hoade Y, Tapper WJ, et al. Recurrent activating STAT5B N642H mutation in myeloid neoplasms with eosinophilia. Leukemia. 2019; 33(2): 415-425, doi: 10.1038/s41375-0180342-3, indexed in Pubmed: 30573779.

83. McKinney M, Moffitt AB, Gaulard P, et al. The genetic basis of hepatosplenic T-cell lymphoma. Cancer Discov. 2017; 7(4): 369-379, doi: 10.1158/2159-8290.CD-16-0330, indexed in Pubmed: 28122867.

84. Pham HaT, Hengstschläger M, Moriggl R. A haunted beast: targeting STAT5B in T-cell neoplasia. Mol Cell Oncol. 2018; 5(3): e1435181, doi: 10.1080/23723556.2018.1435181, indexed in Pubmed: 29876519.

85. Luo Q, Shen J, Yang Y, et al. CSF3R T618I, ASXL1 G942 fs and STAT5B N642H trimutation co-contribute to a rare chronic neutrophilic leukaemia manifested by rapidly progressive leucocytosis, severe infections, persistent fever and deep venous thrombosis. Br J Haematol. 2018; 180(6): 892-894, doi: 10.1111/ bjh.14456, indexed in Pubmed: 27984641.
86. de Araujo ED, Erdogan F, Neubauer HA, et al. Structural and functional consequences of the STAT5B driver mutation. Nat Commun. 2019; 10(1): 2517, doi: 10.1038/s41467-019-10422-7, indexed in Pubmed: 31175292.

87. Gouilleux-Gruart V, Debierre-Grockiego F, Gouilleux F, et al. Activated Stat related transcription factors in acute leukemia. Leuk Lymphoma. 1997; 28(1-2): 83-88, doi: 10.3109/10428199709058334, indexed in Pubmed: 9498707.

88. Gouilleux-Gruart V, Gouilleux F, Desaint C, et al. STAT-related transcription factors are constitutively activated in peripheral blood cells from acute leukemia patients. Blood. 1996; 87(5): 1692-1697, indexed in Pubmed: 8634413.

89. Kovacic B, Stoiber D, Moriggl R, et al. STAT1 acts as a tumor promoter for leukemia development. Cancer Cell. 2006; 10(1): 77-87, doi: 10.1016/j.ccr.2006.05.025, indexed in Pubmed: 16843267.

90. Moriggl R, Sexl V, Kenner L, et al. Stat5 tetramer formation is associated with leukemogenesis. Cancer Cell. 2005; 7(1): 87-99, doi: 10.1016/j.ccr.2004.12.010, indexed in Pubmed: 15652752.

91. Friedbichler K, Kerenyi MA, Kovacic B, et al. Stat5a serine 725 and 779 phosphorylation is a prerequisite for hematopoietic transformation. Blood. 2010; 116(9): 1548-1558, doi: 10.1182/ blood-2009-12-258913, indexed in Pubmed: 20508164.

92. Hoelbl A, Kovacic B, Kerenyi MA, et al. Clarifying the role of Stat5 in lymphoid development and Abelson-induced transformation. Blood. 2006; 107(12): 4898-4906, doi: 10.1182/ blood-2005-09-3596, indexed in Pubmed: 16493008.

93. Ferbeyre G, Moriggl R. The role of Stat5 transcription factors as tumor suppressors or oncogenes. Biochim Biophys Acta. 2011; 1815(1): 104-114, doi: 10.1016/j.bbcan.2010.10.004, indexed in Pubmed: 20969928.

94. Yu H, Jove R. The STATs of cancer - new molecular targets come of age. Nat Rev Cancer. 2004; 4(2): 97-105, doi: 10.1038/ nrc1275, indexed in Pubmed: 14964307.

95. Li G, Miskimen KL, Wang Z, et al. STAT5 requires the N-domain for suppression of miR15/16, induction of bcl-2, and survival signaling in myeloproliferative disease. Blood. 2010; 115(7): 1416-1424, doi: 10.1182/blood-2009-07-234963, indexed in Pubmed: 20008792.

96. Sonkin D, Palmer M, Rong X, et al. The identification and characterization of a STAT5 gene signature in hematologic malignancies. Cancer Biomark. 2015; 15(1): 79-87, doi: 10.3233/CBM-140434, indexed in Pubmed: 25524945.

97. Dagvadorj A, Kirken RA, Leiby B, et al. Transcription factor signal transducer and activator of transcription 5 promotes growth of human prostate cancer cells in vivo. Clin Cancer Res. 2008; 14(5): 1317-1324, doi: 10.1158/1078-0432.CCR-07-2024, indexed in Pubmed: 18316550.

98. Brachet-Botineau M, Polomski M, Neubauer HA, et al. Pharmacological Inhibition of Oncogenic STAT3 and STAT5 Signaling in Hematopoietic Cancers. Cancers (Basel). 2020; 12(1), doi: 10.3390/cancers12010240, indexed in Pubmed: 31963765.

99. Shahmarvand N, Nagy A, Shahryari J, et al. Mutations in the signal transducer and activator of transcription family of genes in cancer. Cancer Sci. 2018; 109(4): 926-933, doi: 10.1111/ cas.13525, indexed in Pubmed: 29417693.

100. Heppler LN, Frank DA. Rare mutations provide unique insight into oncogenic potential of STAT transcription factors. J Clin Invest. 2018; 128(1): 113-115, doi: 10.1172/JCI98619, indexed in Pubmed: 29199995.

101. Tran VT, Phan TT, Mac HP, et al. The diagnostic power of CD117, CD13, CD56, CD64, and MPO in rapid screening acute promye- 
locytic leukemia. BMC Res Notes. 2020; 13(1): 394, doi: 10.1186/ s13104-020-05235-7, indexed in Pubmed: 32847610.

102. Maurer B, Kollmann S, Pickem J, et al. STAT5A and STAT5B-twins with different personalities in hematopoiesis and leukemia. Cancers (Basel). 2019; 11(11), doi: 10.3390/cancers11111726, indexed in Pubmed: 31690038.

103. Pham HaT, Maurer B, Prchal-Murphy M, et al. STAT5BN642H is a driver mutation for T cell neoplasia. J Clin Invest. 2018; 128(1): 387-401, doi: 10.1172/JCI94509, indexed in Pubmed: 29200404.

104. Mosquera Orgueira A, Ferreiro Ferro R, Díaz Arias JÁ, et al. Detection of new drivers of frequent B-cell lymphoid neoplasms using an integrated analysis of whole genomes. PLoS One. 2021; 16(5): e0248886, doi: 10.1371/journal.pone.0248886, indexed in Pubmed: 33945543.

105. Tiacci E, Ladewig E, Schiavoni G, et al. Pervasive mutations of JAK-STAT pathway genes in classical Hodgkin lymphoma. Blood. 2018; 131(22): 2454-2465, doi: 10.1182/blood-2017-11-814913, indexed in Pubmed: 29650799.

106. Zenatti PP, Ribeiro D, Li W, et al. Oncogenic IL7R gain-of-function mutations in childhood T-cell acute lymphoblastic leukemia. Nat Genet. 2011; 43(10): 932-939, doi: 10.1038/ng.924, indexed in Pubmed: 21892159.

107. Shochat C, Tal N, Bandapalli OR, et al. Gain-of-function mutations in interleukin-7 receptor- $\alpha$ (IL7R) in childhood acute lymphoblastic leukemias. J Exp Med. 2011; 208(5): 901-908, doi: 10.1084/ jem.20110580, indexed in Pubmed: 21536738.

108. Zhang J, Ding Li, Holmfeldt L, et al. The genetic basis of early T-cell precursor acute lymphoblastic leukaemia. Nature. 2012; 481(7380): 157-163, doi: 10.1038/nature10725, indexed in Pubmed: 22237106.

109. Roberts KG, Li Y, Payne-Turner D, et al. Targetable kinaseactivating lesions in Ph-like acute lymphoblastic leukemia. N Engl J Med. 2014; 371(11): 1005-1015, doi: 10.1056/NEJMoa1403088, indexed in Pubmed: 25207766.

110. Roberts KG, Morin RD, Zhang J, et al. Genetic alterations activating kinase and cytokine receptor signaling in high-risk acute lymphoblastic leukemia. Cancer Cell. 2012; 22(2): 153-166, doi: 10.1016/j.ccr.2012.06.005, indexed in Pubmed: 22897847.

111. Roberts KG, Yang YL, Payne-Turner D, et al. Oncogenic role and therapeutic targeting of ABL-class and JAK-STAT activating kinase alterations in Ph-like ALL. Blood Adv. 2017; 1(20): 1657-1671, doi: 10.1182/bloodadvances.2017011296, indexed in Pubmed: 29296813.

112. Yoda A, Yoda Y, Chiaretti S, et al. Functional screening identifies CRLF2 in precursor B-cell acute lymphoblastic leukemia. Proc Natl Acad Sci U S A. 2010; 107(1): 252-257, doi: 10.1073/ pnas.0911726107, indexed in Pubmed: 20018760.

113. Lu X, Gross AW, Lodish HF. Active conformation of the erythropoietin receptor: random and cysteine-scanning mutagenesis of the extracellular juxtamembrane and transmembrane domains. J Biol Chem. 2006; 281(11): 7002-7011, doi: 10.1074/jbc. M512638200, indexed in Pubmed: 16414957.

114. Nangalia J, Massie CE, Baxter EJ, et al. Somatic CALR mutations in myeloproliferative neoplasms with nonmutated JAK2. N Engl J Med. 2013; 369(25): 2391-2405, doi: 10.1056/NEJMoa1312542, indexed in Pubmed: 24325359.

115. Klampfl T, Gisslinger H, Harutyunyan AS, et al. Somatic mutations of calreticulin in myeloproliferative neoplasms. N Engl J Med. 2013; 369(25): 2379-2390, doi: 10.1056/NEJMoa1311347, indexed in Pubmed: 24325356.

116. Michalak M, Corbett EF, Mesaeli N, et al. Calreticulin: one protein, one gene, many functions. Biochem J. 1999; 344 Pt 2: 281-292, indexed in Pubmed: 10567207.
117. Wijeyesakere SJ, Rizvi SM, Raghavan M. Glycan-dependent and -independent interactions contribute to cellular substrate recruitment by calreticulin. J Biol Chem. 2013; 288(49): 35104-35116, doi: 10.1074/jbc.M113.507921, indexed in Pubmed: 24100026.

118. Araki M, Yang Y, Masubuchi N, et al. Activation of the thrombopoietin receptor by mutant calreticulin in CALR-mutant myeloproliferative neoplasms. Blood. 2016; 127(10): 1307-1316, doi: 10.1182/blood-2015-09-671172, indexed in Pubmed: 26817954.

119. Elf S, Abdelfattah NS, Chen E, et al. Mutant calreticulin requires both its mutant $\mathrm{C}$-terminus and the thrombopoietin receptor for oncogenic transformation. Cancer Discov. 2016; 6(4): 368-381, doi: 10.1158/2159-8290.CD-15-1434, indexed in Pubmed: 26951227.

120. Edahiro Y, Araki M, Komatsu N. Mechanism underlying the development of myeloproliferative neoplasms through mutant calreticulin. Cancer Sci. 2020; 111(8): 2682-2688, doi: 10.1111/ cas.14503, indexed in Pubmed: 32462673.

121. Chachoua I, Pecquet C, El-Khoury M, et al. Calreticulin mutants in mice induce an MPL-dependent thrombocytosis with frequent progression to myelofibrosis. Blood. 2016; 127(10): 1317-1324, doi: 10.1182/blood-2015-11-679571, indexed in Pubmed: 26608331.

122. de Graaf CA, Metcalf D. Thrombopoietin and hematopoietic stem cells. Cell Cycle. 2011; 10(10): 1582-1589, doi: 10.4161/ cc.10.10.15619, indexed in Pubmed: 21478671.

123. Qian H, Buza-Vidas N, Hyland CD, et al. Critical role of thrombopoietin in maintaining adult quiescent hematopoietic stem cells. Cell Stem Cell. 2007; 1(6): 671-684, doi: 10.1016/j. stem.2007.10.008, indexed in Pubmed: 18371408.

124. Ballmaier M, Germeshausen M. Congenital amegakaryocytic thrombocytopenia: clinical presentation, diagnosis, and treatment. Semin Thromb Hemost. 2011; 37(6): 673-681, doi: 10.1055/s0031-1291377, indexed in Pubmed: 22102270.

125. Seo A, Ben-Harosh M, Sirin M, et al. Bone marrow failure unresponsive to bone marrow transplant is caused by mutations in thrombopoietin. Blood. 2017; 130(7): 875-880, doi: 10.1182/ blood-2017-02-768036, indexed in Pubmed: 28559357.

126. Gurney AL, Carver-Moore K, de Sauvage FJ, et al. Thrombocytopenia in c-mpl-deficient mice. Science. 1994; 265(5177): 1445-1447, doi: 10.1126/science.8073287, indexed in Pubmed: 8073287.

127. Hitchcock IS, Kaushansky K. Thrombopoietin from beginning to end. Br J Haematol. 2014; 165(2): 259-268, doi: 10.1111/ bjh.12772, indexed in Pubmed: 24499199.

128. Kaushansky K. The molecular mechanisms that control thrombopoiesis. J Clin Invest. 2005; 115(12): 3339-3347, doi: 10.1172/ JCI26674, indexed in Pubmed: 16322778.

129. Varghese LN, Defour JP, Pecquet C, et al. The thrombopoietin receptor: structural basis of traffic and activation by ligand, mutations, agonists, and mutated calreticulin. Front Endocrinol (Lausanne). 2017; 8: 59, doi: 10.3389/fendo.2017.00059, indexed in Pubmed: 28408900.

130. Pecquet C, Staerk J, Chaligné R, et al. Induction of myeloproliferative disorder and myelofibrosis by thrombopoietin receptor W515 mutants is mediated by cytosolic tyrosine 112 of the receptor. Blood. 2010; 115(5): 1037-1048, doi: 10.1182/ blood-2008-10-183558, indexed in Pubmed: 19996410.

131. Vainchenker W, Plo I, Marty C, et al. The role of the thrombopoietin receptor MPL in myeloproliferative neoplasms: recent findings and potential therapeutic applications. Expert Rev Hematol. 2019; 12(6): 437-448, doi: 10.1080/17474086.2019.1617129, indexed in Pubmed: 31092065. 
132. Ding J, Komatsu H, Wakita A, et al. Familial essential thrombocythemia associated with a dominant-positive activating $\mathrm{mu}$ tation of the c-MPL gene, which encodes for the receptor for thrombopoietin. Blood. 2004; 103(11): 4198-4200, doi: 10.1182/ blood-2003-10-3471, indexed in Pubmed: 14764528.

133. Abe M, Suzuki K, Inagaki O, et al. A novel MPL point mutation resulting in thrombopoietin-independent activation. Leukemia. 2002; 16(8): 1500-1506, doi: 10.1038/sj.leu.2402554, indexed in Pubmed: 12145691.

134. Moskowitz AJ, Jacobsen E, Ruan J, et al. Durable responses observed with JAK inhibition in T-cell lymphomas. Blood. 2018; 132(Suppl 1): 2922-2922, doi: 10.1182/blood-2018-99112123.

135. Horwitz SM, Feldman T, Hess B, et al. The novel SYK/JAK inhibitor cerdulatinib demonstrates good tolerability and clinical re- sponse in a phase 2a study in relapsed/refractory peripheral T-cell lymphoma and cutaneous T-cell lymphoma. Blood. 2018; 132(Supplement 1): 1001-1001, doi: 10.1182/blood-2018-99-119944.

136. Lv K, Li X, Yu H, et al. Selection of new immunotherapy targets for NK/T cell lymphoma. Am J Transl Res. 2020; 12(11): 7034-7047, indexed in Pubmed: 33312349.

137. Nairismägi M-L, Gerritsen ME, Li ZM, et al. Oncogenic activation of JAK3-STAT signaling confers clinical sensitivity to PRN371, a novel selective and potent JAK3 inhibitor, in natural killer/T-cell lymphoma. Leukemia. 2018; 32(5): 1147-1156, doi: 10.1038/s41375-017-0004-x, indexed in Pubmed: 29434279.

138. Iqbal J, Amador C, McKeithan TW, et al. Molecular and genomic landscape of peripheral T-cell lymphoma. Cancer Treat Res. 2019; 176: 31-68, doi: 10.1007/978-3-319-99716-2 2, indexed in Pubmed: 30596212. 